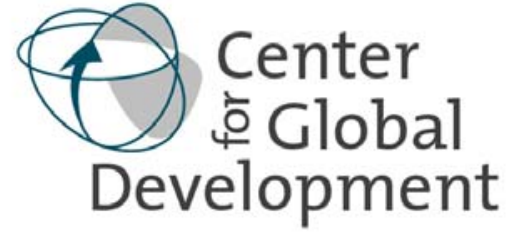

The Road to Pro-Poor Growth:

The Indonesian Experience in Regional Perspective

By C. Peter Timmer

\begin{abstract}
"Pro-poor growth" is the new mantra of the development community. Most donor agencies have active research programs underway to understand the pro-poor process, and the World Bank, with British, French and German bilateral support, is already studying how to operationalize the concept (USAID, 2004; World Bank, 2004). Definitions vary, but they all revolve around connecting the poor to rapid economic growth so there is a concomitant rapid reduction in poverty. What is new is the focus on economic growth as the primary vehicle for sustainable reductions in poverty, with distributional initiatives and processes playing a secondary role. This exploratory essay, commissioned by the Indonesia Project at Australian National University (ANU), places this new interest in pro-poor growth in regional perspective and then attempts to draw historical and policy lessons for Indonesia.1 The main challenge is to link our relatively robust understanding of the growth process with much more limited understanding of distribution processes. A panel data set of eight Asian countries provides grist for the empirical mill.

A revised version of this paper is forthcoming in the Bulletin of Indonesia Economic Studies.
\end{abstract}




\title{
The Road to Pro-Poor Growth: The Indonesian Experience in Regional Perspective $^{1}$
}

\author{
By C. Peter Timmer \\ Senior Fellow, Center for Global Development
}

\author{
Center for Global Development \\ Working Paper \#38 \\ April 2004
}

\begin{abstract}
:
"Pro-poor growth" is the new mantra of the development community. Most donor agencies have active research programs underway to understand the pro-poor process, and the World Bank, with British, French and German bilateral support, is already studying how to operationalize the concept (USAID, 2004; World Bank, 2004). Definitions vary, but they all revolve around connecting the poor to rapid economic growth so there is a concomitant rapid reduction in poverty. What is new is the focus on economic growth as the primary vehicle for sustainable reductions in poverty, with distributional initiatives and processes playing a secondary role. This exploratory essay, commissioned by the Indonesia Project at Australian National University (ANU), places this new interest in pro-poor growth in regional perspective and then attempts to draw historical and policy lessons for Indonesia. ${ }^{2}$ The main challenge is to link our relatively robust understanding of the growth process with much more limited understanding of distribution processes. A panel data set of eight Asian countries provides grist for the empirical mill.
\end{abstract}

\footnotetext{
${ }^{1}$ A revised version is forthcoming in the Bulletin of Indonesia Economic Studies

${ }^{2}$ Inevitably, many intellectual debts are incurred in writing such a paper. I cannot hope to thank all my colleagues in Indonesia and elsewhere who over the years have helped me understand the processes of economic growth and poverty reduction. The intellectual framework used here goes back at least to Food Policy Analysis (1983), and my co-authors for that volume, Wally Falcon and Scott Pearson, have remained close colleagues and sounding boards over the years. The Food Policy Support Activity (FPSA), funded by USAID in Indonesia, has provided continuing support and colleagues for the development of my ideas. And my daughter and co-author on another related manuscript, Ashley, has provided wonderful technical assistance on the data analysis for this paper. Many thanks to all, and blame to none for continuing problems and errors.
} 


\section{Part 1. Introduction and roadmap}

The sources of economic growth and the distribution of its benefits are among the most important topics that economists seek to understand. From The Wealth of Nations (Smith, 1776) to The East Asian Miracle (World Bank, 1993), the Asian experience has shaped that understanding in fundamental ways. These range from Smith's concerns about poor economic governance in China as an impediment to growth in the $18^{\text {th }}$ century, to the World Bank's praise for the region's high savings rates and export orientation as the keys to rapid economic growth in the $20^{\text {th }}$ century. The "miracle," in particular, focused on the stability, or even improvement, in income distribution in these "high-performing Asian economies," during the fastest periods of growth. Rapid, propoor growth was invented in Asia, and Indonesia claimed some of the patent rights.

With the onset of the Asian Financial Crisis in 1997, these experiences came into question. In particular, Indonesia's success, always on the periphery of the experience in the other East Asian tigers, has come under special challenge (Booth, 2002; I. Islam, 2002). With full recovery of the economy not yet in sight, and escalating political disagreements over income distribution and the fate of the poor, this is an opportune time to bring a regional perspective to the nexus between economic growth and income distribution in Indonesia.

This paper is an exploratory effort to examine Indonesia's growth experience and prospects and to see how they are illuminated by recent experiences of her regional neighbors. The focus is on prospects for poverty reduction, but a return to rapid overall economic growth is key to this task. The now well-established links between economic growth and poverty reduction encourage devoting attention to the distributive foundations, and consequences, of the growth process. One important goal of the paper is an attempt to understand the determinants of income distribution in Asia and to connect this understanding to the process of pro-poor growth in Indonesia.

This distributive lens is useful for two related reasons. First, recent research in behavioral economics has shown that inequality per se matters in important ways to economic behavior, and this behavior has consequences for financial markets and economic growth. ${ }^{3}$ Understanding of this behavior by economists provides powerful insights to link expectations about future economic performance with share in that performance, and to subsequent political stability (A. Timmer, 1998).

In turn, political challenges spill directly into economic policy, which affects the speed and direction of economic growth. The key innovation needed here would be the identification of important components of these economic--distribution--political--

\footnotetext{
${ }^{3}$ See the survey on "Risk" in the Economist, January 24-30, 2004, pp. S1-16, for a review of the impact of behavioral economics on understanding global financial markets. Further evidence of how seriously the economics profession is taking the field can be seen in the Nobel Prize awarded to Daniel Kahneman for his pioneering work (with the late Amos Tversky) on the psychological foundations of economic decision making, and the award of the John Bates Clark award to Matthew Rabin for his work in behavioral economics. See the article by Camerer and Thaler in the Summer, 2003, issue of Journal of Economic Perspectives for an appreciation of Rabin's work.
} 
economic cycles, first from the recent literature on political economy dynamics, and then in the empirical record for Asia. ${ }^{4}$

The second reason for interest in income distribution per se motivates this paper directly, but also illustrates the need for the basic understanding discussed above. Highly unequal societies seem to have difficulty sustaining rapid growth in incomes. As an obvious corollary, societies in which income inequality becomes substantially more skewed during the growth process have a doubly difficult time reducing absolute poverty. Growth tends to be slower and it fails to reach the poor. Since the underlying rationale for this paper is to build stronger links between economic growth and poverty reduction-to make growth more "pro-poor"--the relevance of distribution per se, and the underlying connections between growth and the poor, is clear.

The Asian region in general, and Indonesia in particular, present good examples of both distributive dimensions, and this motivates the selection of the eight countries in our panel data set. Changes in incomes of the rich and poor in India and Indonesiaespecially the growing gap between the ends of the income distribution - challenge political systems to help those left behind as the structural transformation in those societies becomes visible. In both countries, however, income distribution, as measured by the Gini coefficient, has been remarkably stable for decades. Understanding the challenges that grow out of these distributional patterns will require insights from behavioral economics.

In other countries in the region, the Philippines and Malaysia, for example, income distribution has been sharply skewed for a long time, with little apparent political resistance to the state of affairs. But the economic performance of the two countries has been sharply different, with absolute poverty nearly eliminated in Malaysia while it remains a visible, even growing, problem in the Philippines. Here the need is to understand the political economy of growth.

A third category of countries - Thailand and China are key examples — started with quite equitable distributions of income, similar to India and Indonesia, only to see the growth process induce a sharp skewing of the distribution. Although the political systems (and institutional histories) are quite different in the two countries, they offer opportunities to see how societies respond to highly visible change in the functional distribution of income. The contrasts should offer analytical insights on whether functional income distribution or income gaps are the main drivers of political discontent during rapid economic growth. Are there policy implications from these experiences as well?

Korea and Pakistan are the two other countries in the panel of data. They are included for two reasons: the availability of reasonably lengthy time series data on income distribution; and the diversity of their economic experiences. Korea is the fastest growing economy in the region since 1960, so it presents an opportunity to study the

\footnotetext{
4 A paper pursuing these dynamics in the Asian context is underway. See Timmer and Timmer (forthcoming).
} 
impact of substantial structural transformation on income distribution. Of the countries in this sample, Pakistan started with the lowest per capita income and has not grown rapidly, demonstrating that convergence is not an automatic process.

The paper proceeds as follows. A brief statistical overview of the eight countries in the sample compares their historical paths of income growth and distribution. This description is limited by the availability of high quality data on income distribution. Still, the historical time period is long enough, and the number of observations within the time period adequate in all eight countries, to justify a serious econometric search for patterns.

This search initially uses the Gini coefficient as the measure of income distribution, but behavioral economists often argue that limited insights come from Gini coefficients as indicators of relevant distributive issues. Accordingly, levels and changes in the income gap between rich and poor in these countries are also utilized. This gap is measured as the absolute difference between the \$PPP per capita incomes of the richest and poorest quintiles at each period in time for which income distribution data are available. There is no question that income gaps have more political resonance than Gini coefficients, although relatively little economic analysis has compared the two measures.

It seems likely that growing gaps, because they are so visible, must be managed politically in a way that defuses tensions between the rich and poor, otherwise the growth process itself is threatened. This political "management" can take various forms, from autocratic repression in Indonesia, to open racial preferences in Malaysia, to populist rhetoric in Thailand, and to extreme agricultural protection in Korea. Democracy is likely to offer different opportunities, and challenges, than face autocratic or repressive regimes. The Indonesian experience since 1999 is particularly revealing.

The comparative section concludes with a description of the most basic dimensions of "pro-poor growth." To keep the analysis simple and directly comparable across all eight countries, the rate of growth in the real per capita incomes of the bottom quintile of the income distribution is plotted relative to growth in average per capita incomes for the whole economy for the same period. This basic pro-poor growth diagram shows a common result: for long time periods, the observations cluster around the 45 degree line. Most of the variance across countries is in the overall rate of growth rather than how well the poor connect to it. For shorter periods, or important sub-periods, however, there is substantial variance in this connectivity. Disaggregated examples from China and Indonesia illustrate the points.

Part 3 turns the discussion to the Indonesian example by outlining a very brief history of the country's experience with economic growth and poverty reduction. Economic growth in Indonesia has always benefited the poor. There are episodes when income inequality increased and episodes where it decreased, so Indonesia has experienced both "weak" and "strong" pro-poor growth. During economic decline and crises, the poor have been badly impacted. But there are no episodes where the poor were worse off during periods of economic growth (with the possible exception of rural areas during the "Dutch Disease" era in the mid- to late-1970s). 
This performance was based on a conscious strategy of integrating the macro economy with the household economy by lowering the transactions costs of operating in the markets - factor markets and product markets - that provide links between the two levels of the overall economy. Luck also played a role, as powerful new agricultural technology became available just as the country was putting in place the economic strategy to make it effective. Later, foreign direct investment arrived from Northeast Asia just as Indonesia needed to restructure its manufacturing sector to be more labor intensive and export oriented.

Part 4 attempts to model Indonesia's experience with pro-poor growth, drawing from regional insights as well. The model is hard to test formally because there has been relatively little long-run change in the overall distribution of income in Indonesia, although it does change significantly during short periods. These periods are usually measured in 3-year increments because of the availability of SUSENAS data. ${ }^{5}$ The shortrun variance in the "elasticity of connection" of the poor to economic growth is mostly driven by macro economic policy, especially control of inflation and management of the real exchange rate, and secondarily by sector-specific trade and investment policies (Timmer, 1997, 2002). The interaction between macro policy and poverty reduction is especially important in Indonesia because of the strong interface between the tradable and non-tradable sectors. Rapidly rising demand for the goods and services produced by the non-tradable sector, mostly in rural areas, seems to be the short-run driver for pulling underemployed labor out of rural households, and thus out of poverty. The interface between the tradable and non-tradable sectors is mediated by both demand and supply responses.

Investments in agricultural infrastructure have had a major impact on making overall economic growth more pro-poor. When productivity enhancing agricultural technology was available and profitable, growth was "strongly" pro-poor. Much of the rural infrastructure was built using labor-intensive techniques, with the jobs created "selftargeted" to the poor because of the low wages paid. The financing for these projects came mostly from the Central Government, whose budget until the early 1980s depended first on foreign aid and then on oil revenues, and this was the era of the most massive rural investments (Papanek, 2004). This sectoral focus on the sources of pro-poor growth (as opposed to its impact) is controversial and needs careful methodological and empirical investigation (Sarris, 2001). But the initial evidence is overwhelmingly supportive of the view that active policy concern for a dynamic rural economy, including, at times, active protection of the rice economy from depressed prices in world markets, made the overall economic growth process more pro-poor than it would have been otherwise.

\footnotetext{
${ }^{5}$ SUSENAS, the Indonesian acronym for the National Socio-Economic Survey conducted by the Central Bureau of Statistics, provides detailed expenditure data on more than 60,000 households every three years. Less detailed data from a "core" questionnaire are available annually for about 200,000 households. Because of differences in approach, it has been difficult to match up results from the two different questionnaires.
} 
Part 5 addresses important trade-offs that emerged between overall economic growth and growth in the incomes of the poor, as a way to frame the current policy debate. Microand sectoral policies, often implemented in the name of poverty reduction or improved income distribution, usually caused economic growth to be slower than the macro policy environment would have permitted. Only the agricultural sector interventions have a serious claim to poverty reduction, and that claim suggests a trade-off between growth and pro-poor growth. In other areas - minimum wage legislation and specific industry protection, for example - the dead-weight losses also hurt the poor as well as economic growth. Trade-offs may also have existed in public investments, as infrastructure investments had a more immediate impact on the poor than investments in human capital, which were the long-run route out of poverty. A final trade-off was apparent in the realm of political economy, as "payoffs" to enhance political stability, for example, to rice farmers in East Asia, cost the economy in the short run but ensured long-run sustainability of the overall growth strategy. Indonesia grappled with this particular trade-off in the run-up to the 2004 Presidential election.

Which households are poor is often judged by the real wages they earn, as the poor usually have little to sell but their own labor. But the link between real wages for unskilled labor and the extent of poverty is more complicated than expected, and this raises quite basic issues about the definition and measurement of poverty. Especially during the Asian Financial Crisis, from which Indonesia has not yet recovered fully in macro economic terms, household expenditure surveys (SUSENAS) are telling a different story than data on real wages (Papanek, 2004). Part of the problem is the difficulty of choosing a reliable deflator for nominal wages during a period of rapid relative price changes. Part of the problem is the changing structure of employment between formal and informal, and the possibility of a short-run break in the strong integration of labor markets seen historically. And part of the problem may be a growing importance of self-employment and remittances in stabilizing household expenditures. This is a major research topic for the future, because reconciling these two views on the current status of the economy and its impact on the poor will be crucial to designing propoor growth strategies that work as well in the future as they did during the three decades of rapid economic growth under the Suharto regime. 


\section{Part 2. Indonesia's growth and poverty record in regional perspective}

Figure 1 plots the historical record for real per capita incomes (on a log scale) against income distribution (as measured by Gini coefficients) for the eight countries in the sample. It is clear that not all growth patterns are the same, as experiences in China and Thailand, for example, stand in sharp contrast to those in India and Pakistan. A rough categorization of the historical experience in these eight countries is shown in Table 1.

The concentration of countries in the lower left "triangle" of the matrix in Table 1 is striking. Medium and fast economic growth is associated with low inequality, or with low, rising to high, inequality. With fuller data on more Asian countries, and a longer time horizon, it is likely that more of the cells would have entries. Bangladesh would probably fit in the cell of "slow growth and low/stable inequality." Myanmar and possibly Cambodia are likely to fit in the cell of "slow growth and low-to-high inequality." India and Pakistan seem on the verge of shifting to the center cell, with medium growth and a transition from low to high inequality.

Intriguingly, there are no apparent representatives for the lower right cell, where fast economic growth would exist with high and stable income inequality. The political dynamics that make this an "empty box" would seem to be especially troubling for China and Thailand.

\section{Are the data robust enough for more extensive analysis?}

In a recent paper, Galbraith and Kum (2003) argue that Asian income inequality, as measured by household expenditure surveys "... is much higher than a casual reading of the D \& S data would suggest." These surveys, compiled by Deininger and Squire (1996, with updates), have been the source of a veritable avalanche of empirical work on the impact of income distribution on economic growth (and vice versa). However, attempts to understand the forces driving differences in income distribution itself, across countries and over time, have been much less successful (Kraay, 2004). Galbraith and Kum argue that one reason is the poor quality of the income distribution data themselves.

Their conclusion, that the Deininger-Squire (DS) data have very limited usefulness, presents a direct challenge to the analysis conducted in this paper. Fortunately, their conclusion is not only wrong, but their proposed alternative - to utilize data on dispersion of manufacturing wages, along with two structural variables, as a substitute for the DS data--is basically irrelevant in Asia. The empirical results reported below show that the key structural dimensions of each economy, along with differences in the food and agricultural sectors, contribute significantly to understanding differences in income distribution across countries and over time.

Several elements of economic structure are particularly important: (1) the relative share of the food and agricultural economy in overall economic activity; (2) relative labor productivity - reflected in wages - in agriculture and the rest of the economy; (3) the role

of non-labor income in these economies, especially income from property ownership; and 

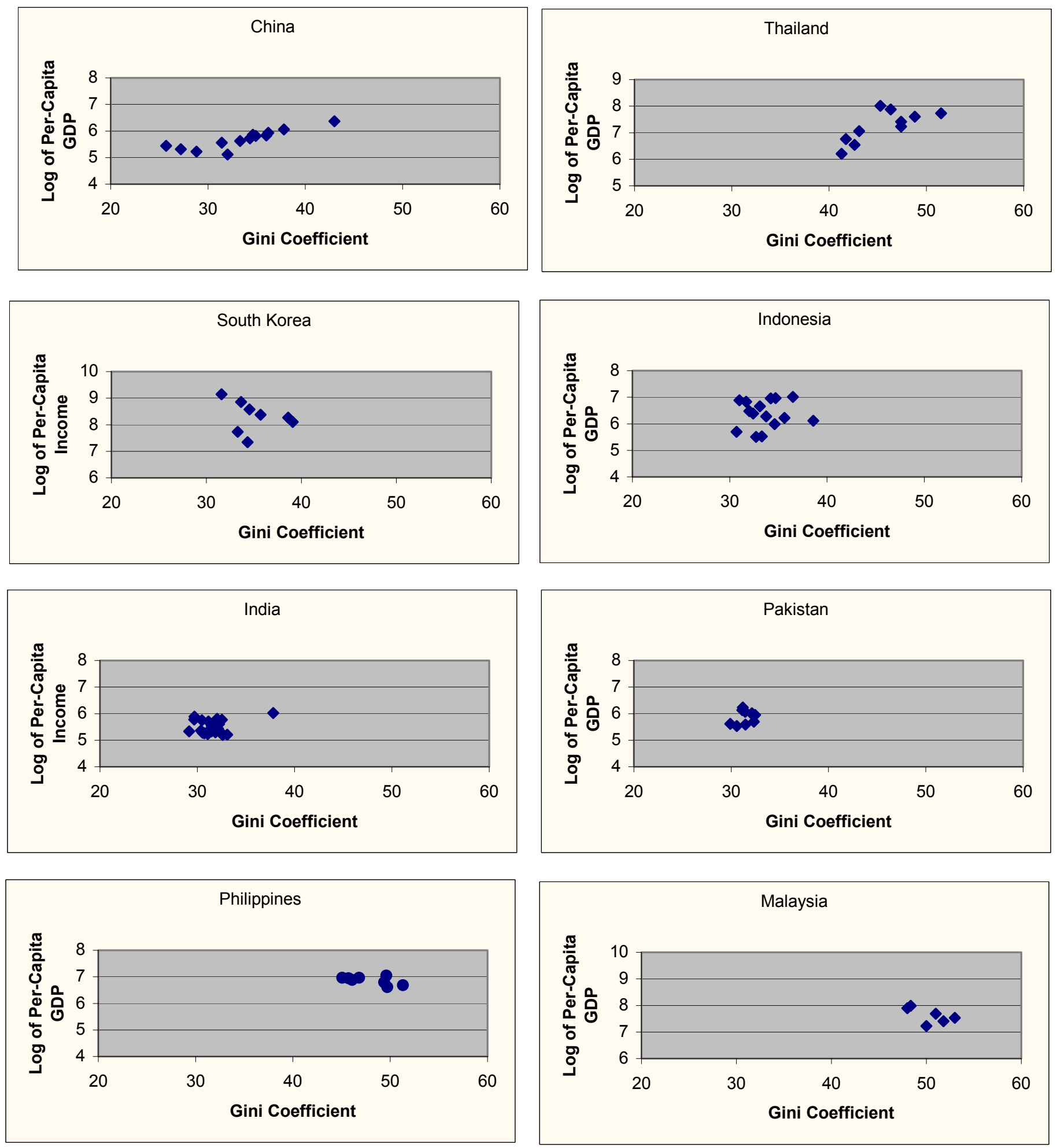

Figure 1. Comparing Changes in Per Capita Incomes and Income Distribution in Eight Countries in Asia 
Table 1. Countries categorized by degree of income inequality and economic growth

Income inequality over time

\begin{tabular}{l|cccc}
\cline { 2 - 5 } Economic & \multicolumn{2}{c}{ Low/stable } & low to high & high/stable \\
Growth & XXX & XXX & Philippines \\
Medium & $\begin{array}{l}\text { India } \\
\text { Indonesia } \\
\text { Pakistan }\end{array}$ & XXX & Malaysia \\
Fast & Korea & China & XXX \\
& & Thailand &
\end{tabular}

Note: Average annual economic growth from 1960 to 1999 was as follows (in percent per year per capita): China, 4.21; India, 2.75; Indonesia, 3.39; Korea, Rep., 5.92; Malaysia, 3.87; Pakistan, 3.38; Philippines, 1.29; Thailand, 4.61. "Slow" economic growth was less than 2.5 percent per year, "medium" from 2.5 to 4 percent per year, and "fast" over 4 percent per year. Countries with "low/stable" inequality maintained Gini coefficients of less than 35 for the period of observation. "High/stable" countries had Gini coefficients over 40 the entire time. The "low to high" countries transitioned from Gini coefficients in the 30 s to coefficients in the 40 s.

(4) the role of the informal sector, especially services - mostly producing non-tradables in both the rural and urban economies.

Because poverty and hunger are so closely linked, with many poverty lines defined in terms of food intake, food policy variables are likely to play a significant role in explaining differences in income distribution. In particular, price policy for staple foods, especially rice, has an immediate impact on both food consumption and the profitability of an important rural activity, rice production. Food prices more generally are likely to affect household caloric intake in a systematic manner, with poorer households affected more significantly than rich households. Thus residuals from a simple regression relating the logarithm of household incomes to food energy (kilocalories) intake should help explain income distribution (although the causation probably runs the other direction). Finally, again controlling for income, the quality of the diet might also be an indicator of significant differences in income distribution across countries and within countries across time. Dietary quality is measured here by the starchy staple ratio--the ratio of food energy from starchy foods such as cereals and tubers.

Understanding changes in income distribution, which have been quite substantial for several of these countries over the past four decades, requires an understanding of the evolving roles of these different structural and policy components of each country's economy. Only rough proxies for each of these structural and policy components are available for all of the countries in the sample. But even an approach as simple as 
including the savings rate to proxy for non-labor income, the share of services in the economy for the informal sector, and stage in the agricultural transformation for the structural variable produces significant contributions to the predicted Gini coefficient for each country over time. A simple price variable measuring the marketing margin for rice from farm to retail also has power.

Interestingly, when these variables are included in the predictive equation, the Theil coefficient on manufacturing wage dispersion drops out entirely! So not only are the wage dispersion data not superior to the Asian income inequality data, as argued by Galbraith and Kum (2003), they do not appear to be related to it in any significant way. As best the analysis can indicate, the Theil distribution data on wage dispersion basically substitute for country-specific effects. Indeed, a country's data on GDP per capita dominate statistically the log of the Theil coefficient in all the results. Table 2 shows these results, with equations 1,2 , and 3 reporting the Theil results.

For the broader purposes here, equations 4,5 and 6 provide the key results. In equation 4 , all of the structural and food policy variables have the expected sign and are significant, confirming the hypothesis that income distribution does depend in predictable ways on economically plausible variables. Equation 5 tests, roughly, for the "Kuznets effect," by inserting the rate of economic growth into the equation. Several other variables drop out, but the main results remain and a positive impact on the Gini coefficient is felt from more rapid growth, although the statistical significance just misses the five percent level. Thus there is a hint that rapid growth increases inequality for the whole sample.

Equation 6 drops the fixed effects specification to test whether Indonesia is an outlier in this panel of eight countries. Two variables reverse sign when the Indonesia country dummy is included - Wagegap and Ssrresid - but these are the least robust variables in other specifications as well. Still, the Indonesia country dummy is significantly negative, indicating that income distribution is more equal in the country, even when controlling for the structural and food policy variables. The country discussion and model of propoor growth attempt to explain why this might be so.

All of the analysis conducted so far has used the Gini coefficient as the relevant measure of income distribution. As argued earlier, growing gaps between the poor and the rich are more visible, and thus more politically threatening, than statistical measures of disparity that are hard to measure and even harder to explain to policy makers and the press. When income or expenditure data are presented by income quintile as well as in summary form as Gini coefficients, it is possible to calculate these gaps. The definition used here is simply the difference between the incomes of the bottom and top quintiles, in constant \$PPP for comparability across countries and time period. Further insights are gained by also examining this gap in relation to the per capita income of the poor.

Several relevant statistics using this income gap are presented in Table 3. In both absolute and relative terms, there is substantial variation in the gaps. To standardize the comparisons to some extent, the growth in the income gap over a 20 year period is 
Table 2. Explaining the (log of the) Gini coefficient across time and countries (for Indonesia, Malaysia, Philippines, Thailand, India, Pakistan, South Korea, and China)

\begin{tabular}{|c|c|c|c|c|c|c|}
\hline \multirow{2}{*}{$\begin{array}{l}\text { Independent } \\
\text { Variable }^{6}\end{array}$} & \multicolumn{4}{|c|}{ Equation Number } & \multirow[b]{2}{*}{5} & \multirow[b]{2}{*}{6} \\
\hline & 1 & 2 & 3 & 4 & & \\
\hline Constant & $\begin{array}{r}1.853 \\
(7.9)\end{array}$ & $\begin{array}{r}-2.068 \\
(5.9)\end{array}$ & $\begin{array}{r}0.4686 \\
(0.9)\end{array}$ & $\begin{array}{c}1.628 \\
(9.2)\end{array}$ & $\begin{array}{l}1.635 \\
(9.2)\end{array}$ & $\begin{array}{r}0.8358 \\
(2.2)\end{array}$ \\
\hline Logsect & $\begin{array}{c}0.4160 \\
(9.5)\end{array}$ & $\begin{array}{r}0.7498 \\
(11.3)\end{array}$ & $\begin{array}{c}0.4828 \\
(4.6)\end{array}$ & $\begin{array}{r}0.4322 \\
(10.1)\end{array}$ & $\begin{array}{r}0.4563 \\
(10.8)\end{array}$ & $\begin{array}{r}0.4948 \\
(5.9)\end{array}$ \\
\hline Wagegap & $\begin{array}{c}-0.0094 \\
(0.7)\end{array}$ & $\begin{array}{c}0.0003 \\
(0.1)\end{array}$ & $\begin{array}{c}-0.0314 \\
(4.6)\end{array}$ & $\begin{array}{c}0.0114 \\
(2.4)\end{array}$ & $\begin{array}{c}0.0131 \\
(2.7)\end{array}$ & $\begin{array}{r}-0.0360 \\
(7.0)\end{array}$ \\
\hline Gdpserv & $\begin{array}{r}0.0022 \\
(1.8)\end{array}$ & $\begin{array}{c}-0.0103 \\
(4.7)\end{array}$ & $\begin{array}{c}0.0161 \\
(6.3)\end{array}$ & $\begin{array}{c}0.0020 \\
(2.0)\end{array}$ & -- & $\begin{array}{c}0.0107 \\
(5.8)\end{array}$ \\
\hline Saving & $\begin{array}{r}00025 \\
(2.2)\end{array}$ & $\begin{array}{c}-0.0126 \\
(8.1)\end{array}$ & $\begin{array}{c}0.0082 \\
(5.2)\end{array}$ & $\begin{array}{l}0.0013 \\
(2.0)\end{array}$ & -- & $\begin{array}{c}0.0095 \\
(8.3)\end{array}$ \\
\hline Ricertof & $\begin{array}{r}0.0039 \\
(0.2)\end{array}$ & $\begin{array}{c}0.0812 \\
(2.2)\end{array}$ & $\begin{array}{c}0.1690 \\
(2.8)\end{array}$ & $\begin{array}{c}0.0432 \\
(2.8)\end{array}$ & $\begin{array}{r}0.0364 \\
(2.4)\end{array}$ & $\begin{array}{c}0.1945 \\
(5.5)\end{array}$ \\
\hline Ssrresid & $\begin{array}{r}-0.2100 \\
(1.1)\end{array}$ & $\begin{array}{c}-0.1607 \\
(1.4)\end{array}$ & $\begin{array}{c}-0.1306 \\
(0.7)\end{array}$ & $\begin{array}{c}-0.4549 \\
(2.7)\end{array}$ & $\begin{array}{r}-0.7455 \\
(5.4)\end{array}$ & $\begin{array}{c}0.5258 \\
(3.0)\end{array}$ \\
\hline Kcalresid & $\begin{array}{c}-0.00008 \\
(2.6)\end{array}$ & $\begin{array}{c}-0.00031 \\
(8.8)\end{array}$ & $\begin{array}{c}-0.00039 \\
(6.8)\end{array}$ & $\begin{array}{c}-0.00007 \\
(2.6)\end{array}$ & $\begin{array}{c}-0.00005 \\
(1.8)\end{array}$ & $\begin{array}{c}-0.00037 \\
(8.2)\end{array}$ \\
\hline Loggdp & $\begin{array}{c}-0.0181 \\
(0.8)\end{array}$ & $\begin{array}{r}0.4107 \\
(17.1)\end{array}$ & -- & -- & -- & -- \\
\hline Gdpgrow & -- & -- & -- & -- & $\begin{array}{c}0.1949 \\
(1.9)\end{array}$ & -- \\
\hline Logtheil & $\begin{array}{c}-0.0194 \\
(1.6)\end{array}$ & $\begin{array}{c}-0.0022 \\
(0.2)\end{array}$ & $\begin{array}{c}-0.0668 \\
(3.1)\end{array}$ & -- & -- & -- \\
\hline Indonesia & -- & -- & -- & -- & -- & $\begin{array}{r}-0.2689 \\
(8.1)\end{array}$ \\
\hline Fixed Effects? & $\mathrm{Y}$ & $\mathrm{N}$ & $\mathrm{N}$ & $\mathrm{Y}^{7}$ & $\mathrm{Y}$ & $\mathrm{N}$ \\
\hline $\begin{array}{l}\text { R squared } \\
\text { Rho }\end{array}$ & 0.966 & 0.820 & 0.517 & 0.945 & 0.949 & 0.611 \\
\hline
\end{tabular}

calculated for all eight countries, and this varies from just $\$ 1,109$ in India to $\$ 9,812$ in Malaysia (in constant \$PPP). An alternative relative measure may have more political impact - the size of the income gap compared with the per capita income of the bottom quintile of the income distribution. Here too there is great variance, ranging from a low

\footnotetext{
6 -statistics are shown in parentheses. For variable means and definitions, see Appendix Table 1. In order for each country to have roughly equal weight in the panel regression analysis, the dependent variable — the log of the Gini coefficient—is made up of linearized annual data from the actual Gini observations in the World Bank data set. Regressions run with the actual observations themselves obviously have fewer observations and several statistical results are less robust, but the pattern of results is the same.

${ }^{7}$ When this equation is run with separate country intercepts instead of fixed effects, the country coefficients are as follows $(t$-statistics in parentheses): China, -0.1209 (3.7), India, -0.1812 (4.7), Indonesia, -0.1058 (3.0), Korea, 0.1113 (2.6), Pakistan, -0.2177 (4.7), Malaysia, 0.2734 (5.8), Philippines, 0.1962 (5.7). The intercept for Thailand is part of the overall intercept.
} 
of 3.39 times in Pakistan (and 3.93 in Indonesia) to 10.99 in Malaysia (and 8.76 in the Philippines). ${ }^{8}$

Despite the political resonance of growing income gaps, especially when they are visible from the conspicuous consumption of the rich, Table 3 quantifies what might as well be called the "iron law of distribution." Income gaps between the rich and poor are a fact of economic life, and the gaps increase faster, the faster the economy grows.

Even with only eight countries in the sample, this is a powerful statistical reality. A simple regression relating the growth rate of per capita incomes and the (log of the) income gap at the start of the period explains more than 95 percent of the variation in the (log of the) change in the income gap over 20 years. ${ }^{9}$

Perhaps the simplest summary of this comparative perspective on economic growth and income distribution in these eight countries examines the experience with "pro-poor growth" directly. Figure 2 plots the growth in per capita incomes of the "poor," the bottom quintile in the income distribution, against growth in average per capita incomes for the overall economy during the same time period. The basic picture is well known (Kraay, 2004). The long-term performances of all eight countries are in the northeast quadrant and lie close to the 45 degree line, where there is equal growth in the average per capita income and per capita income of the poor. Of course, as noted above, this "good" performance is completely consistent with rapidly growing gaps between the income of the poor and rich.

Figure 2 demonstrates two key points about pro-poor growth. First, over long periods of time, there is remarkable stability in the close relationship between overall economic growth and growth in incomes of the bottom quintile. Second, however, there is tremendous variance from one time period to another. In China, for example, economic growth was explosively pro-poor in the initial liberalization period that opened up the rural economy, from 1980 to 1984. Overall economic growth was a remarkable 8 percent per year per capita, but the incomes of the bottom quintile, nearly all in rural areas, grew by 14.6 percent per year! Since 1984, the growth process has led to sharply skewed incomes, as rural areas and the interior have failed to match the rapid commercialization of the coastal and urban areas. Average per capita incomes have still increased by a remarkable 6 percent per year, but incomes of the bottom quintile have grown only 1.9

\footnotetext{
${ }^{8}$ Regressions similar to those presented in Table 2 for Loggini as the dependent variable were run with the $\log$ of the income gap as dependent variable, as well as the relative gap as just discussed. In general, the results were similar to those for Loggini and are not presented here in the interests of space.

${ }^{9}$ The actual regression is as follows (with $t$-statistics in parentheses):

LDGAP20 $=0.798+0.426 *$ PCIGROW $+0.692 *$ LGAPSTART, where

$\begin{array}{llll}(0.9) & (9.2) & (5.4) & (\mathrm{R} \text { squared }=0.956)\end{array}$

LDGAP20 = Logarithm of the change in the income gap over 20 years (calculated from the rate for the entire time period;

PCIGROW $=$ Growth rate in per capita income over the entire time period, in percent per year; and LGAPSTART $=$ Logarithm of the income gap at the start of the period, in \$PPP.
} 
Table 3. Changes in Income Gaps Between the "Rich" and "Poor"

\begin{tabular}{|c|c|c|c|c|c|c|c|c|}
\hline \multirow[b]{2}{*}{ Country } & \multirow{2}{*}{$\begin{array}{l}\text { Time } \\
\text { Period }\end{array}$} & \multicolumn{2}{|c|}{ \$PPP p.c. Income } & \multicolumn{3}{|c|}{ \$PPP Income Gap } & \multicolumn{2}{|c|}{ Changes in Gap } \\
\hline & & Start & End & Start & End & $\begin{array}{l}\text { 1tiple of Q1 } \\
\text { of Period }\end{array}$ & Actual & "20 Year" \\
\hline China & $80-98$ & $\begin{array}{ll}\text { Q1 } & 425 \\
\text { Q5 } & 1965\end{array}$ & $\begin{array}{l}960 \\
7640\end{array}$ & 1540 & 6680 & 6.96 & 5140 & 6325 \\
\hline India & $60-97$ & $\begin{array}{l}\text { Q1 } 352 \\
\text { Q5 } 1734\end{array}$ & $\begin{array}{l}871 \\
4980\end{array}$ & 1382 & 4109 & 4.72 & 2727 & 1109 \\
\hline Indonesia & $67-02$ & $\begin{array}{lc}\text { Q1 } & 387 \\
\text { Q5 } & 1913\end{array}$ & $\begin{array}{l}1609 \\
7939\end{array}$ & 1525 & 6330 & 3.93 & 4805 & 1915 \\
\hline Korea & $65-93$ & $\begin{array}{lc}\text { Q1 } & 542 \\
\text { Q5 } & 3908\end{array}$ & $\begin{array}{l}4373 \\
23046\end{array}$ & 3366 & 18674 & 4.27 & 15308 & 8079 \\
\hline Malaysia & $70-95$ & $\begin{array}{lc}\text { Q1 } & 522 \\
\text { Q5 } & 8178\end{array}$ & $\begin{array}{l}1954 \\
23422\end{array}$ & 7656 & 21468 & 10.99 & 13813 & 9812 \\
\hline Pakistan & $69-96$ & $\begin{array}{lc}\text { Q1 } & 415 \\
\text { Q5 } & 1820\end{array}$ & $\begin{array}{l}917 \\
9030\end{array}$ & 1406 & 3113 & 3.39 & 1707 & 1128 \\
\hline Philippines & s 61-97 & $\begin{array}{l}\text { Q1 } 435 \\
\text { Q5 } 5851\end{array}$ & $\begin{array}{l}900 \\
8785\end{array}$ & 5416 & 7886 & 8.76 & 2470 & 1257 \\
\hline Thailand & $62-98$ & $\begin{array}{lc}\text { Q1 } & 479 \\
\text { Q5 } & 2982\end{array}$ & $\begin{array}{l}1997 \\
15178\end{array}$ & 2503 & 13181 & 6.60 & 10679 & 3796 \\
\hline
\end{tabular}

Note: The "20 Year" gap figure standardizes the change in the income gap over a 20 year period, assuming the rate of change in the gap is the same per year as for the entire period shown in the table. Q1 and Q5 refer to the per capita incomes of the bottom and top quintiles, respectively.

percent per year from 1984 to 1998. From what must have been the most pro-poor growth episode in history, China has reverted to one of the least pro-poor patterns in Asia.

In some ways, the Indonesian example shown in Figure 2 is even more dramatic. Over the entire time period, from 1967 to 2002, Indonesia marked up a credible 4.15 percent increase in average per capita incomes at the same time that the bottom quintile shared exactly in that growth (in percentage terms). But this long-term perspective masks two fundamentally different episodes. From 1967 to 1996, average per capita incomes increased 5.1 percent while incomes of the bottom quintile also increased by 5.1 percent. From 1996 to 2002, however, average per capita incomes dropped by 0.4 percent per year while incomes of the bottom quintile were falling 0.3 percent per year. This reversal of fortune is one of the most dramatic in recent history. Indeed, as Figure 2a shows, there is considerable variance in the "pro-poorness" of growth in Indonesia when each available time period is plotted separately.

To summarize the regional story, all the structural and policy variables for which there are reasonable proxies in the empirical record, are significant and have the expected sign, at least in the most basic specifications as exemplified by equation 4 in Table 2.

Maintaining greater parity between agricultural and non-agricultural incomes is good for income distribution. Indeed, this is perhaps the most robust statistical result reported. 


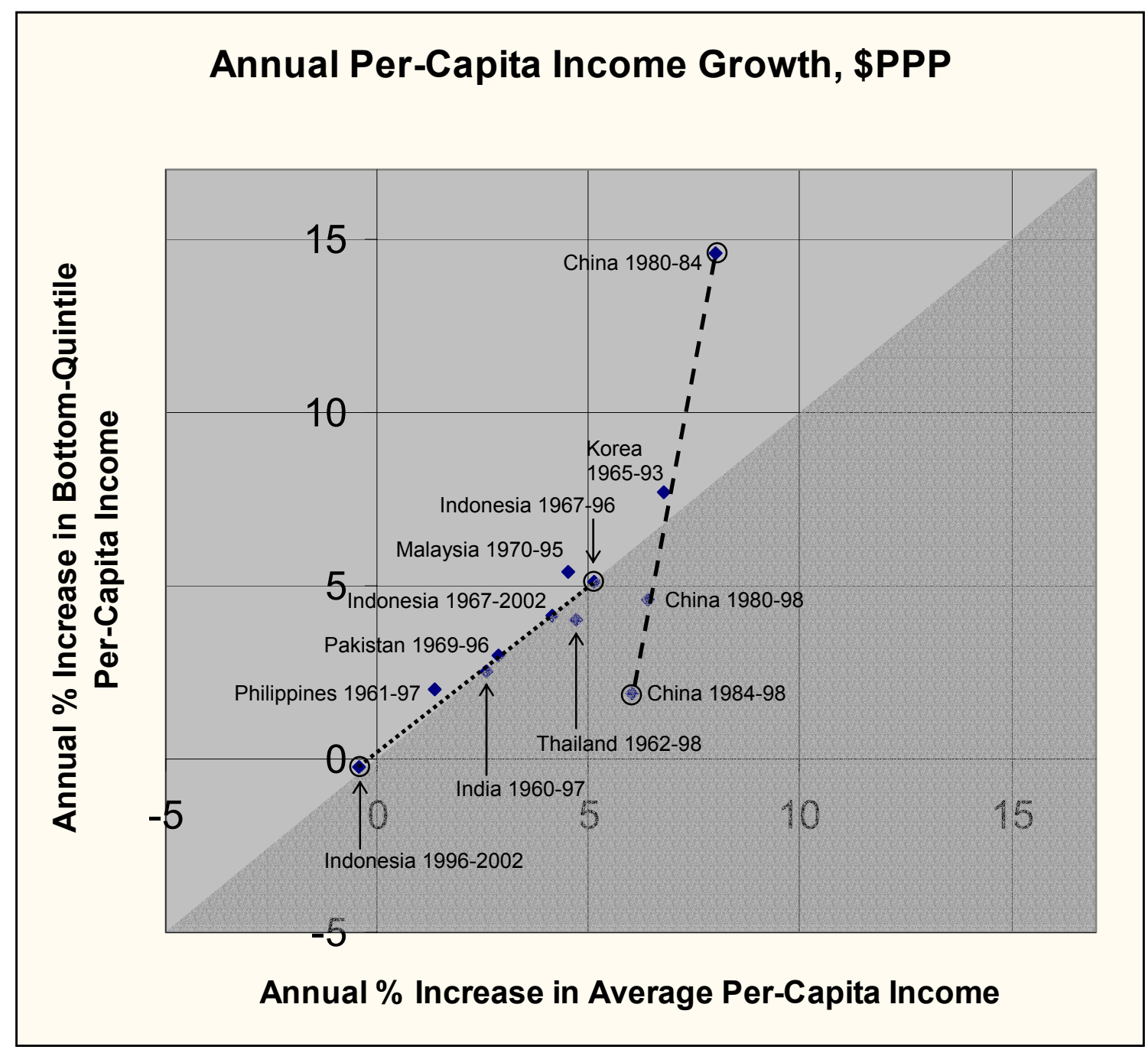

Figure 2. Income Growth for the Bottom Quintile Plotted Against Growth for Average Per Capita Incomes, for Eight Countries in Asia

But a higher savings rate, implying greater total returns to capital, worsens income distribution, as does a higher share of services in GDP. If the services sector, at the margin, is made up of low-productivity workers fleeing rural poverty, this result makes sense.

The food and agricultural variables that operate primarily on the demand side also have surprising power. A widening marketing margin for rice between the farm and retail levels widens income distribution, and it is no wonder that many countries attempt to squeeze the margin through public interventions on behalf of both producers and consumers (Timmer, 1996). But this can have devastating consequences for the budget and/or the development of a viable private marketing sector, as China especially learned in the 1980s. It is also intriguing to see the role that dietary quantity and quality play in 


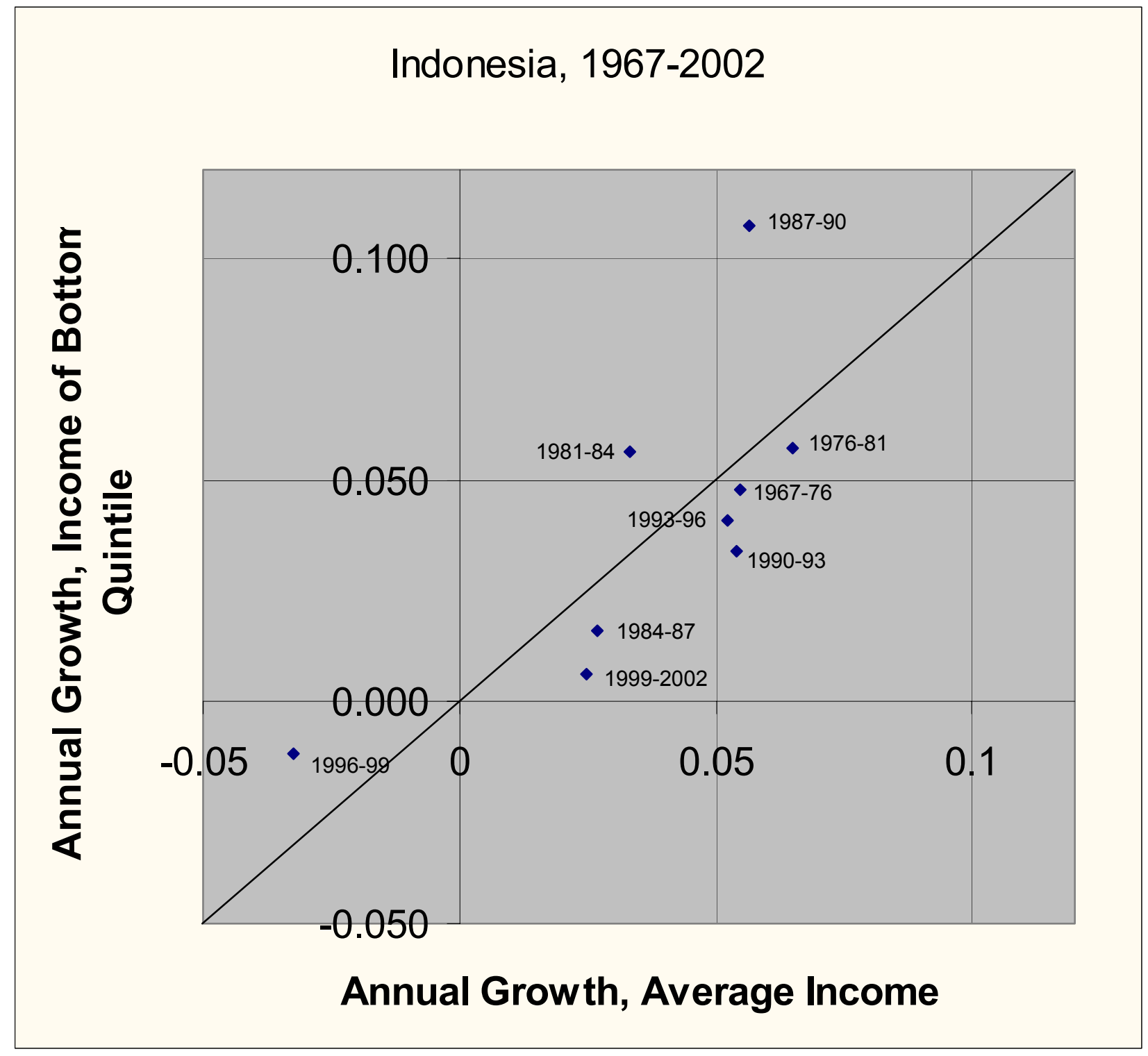

Figure 2a. Income Growth for the Bottom Quintile Plotted Against Growth for Average Per Capita Incomes, for Separate Time Periods in Indonesia

(or are affected by) income distribution, but further analysis is needed, probably on a country by country basis, to tease out serious policy implications. This work is underway in Indonesia (Molyneaux, 2003).

Where does Indonesia fit? At one level, as Figure 2 shows, Indonesia can be said to fit at both extremes and in the middle of the Asian experience. That is, its long-run experience with pro-poor growth is not quite as good as Malaysia, Thailand or China, but it is better than the Philippines, Pakistan, and India. When the Suharto era is split out from the years 
of the Financial Crisis, however, then Indonesia's record is both the worst (from 1996 to 2002) and among the best (1967-1996). This extraordinary variance begs for explanation. With the regional record for perspective, it will be very instructive to understand this varied country experience in more detail.

\section{Historical context}

Under Dutch colonial rule, which started in the $15^{\text {th }}$ century and ended effectively with the Japanese occupation in 1942 and the Indonesian war for Independence in 1945, the trade and tax regime favored Dutch extraction of income. There was especially poor economic management during the Great Depression, as the Dutch forced the Netherland East Indies to stay on the Gold Standard well after their regional competitors, including the Japanese, devalued. Still, the colonial authorities built a significant network of irrigation canals, roads, ports and shipping facilities, and railroads. There was very little investment in education of the local population. As best the historical records can say there was severe poverty in the mid- $19^{\text {th }}$ century, which fell gradually until the late 1920 s, and then there were very rapid increases in poverty until after WWII (van der Eng, 2002).

After Independence was won in 1949, the Sukarno government put "politics in command," with severe neglect of agriculture, "inward looking" development policy, and economic and political chaos by the mid-1960s. The result was falling incomes and hyper-inflation, impacting virtually everyone, but especially the poor. In 1968, Gunnar Myrdal's judgment in Asian Drama was that "no economist holds out any hope for Indonesia." The post-war recovery had helped reduce the deep poverty seen during the Great Depression and the War, but then poverty increased rapidly as inflation soared and the economy collapsed. Probably 80 percent of the population was "absolutely poor" during the turmoil in the transition between the Sukarno and Suharto regimes late in 1966 and early in 1967, with average food energy intake less than 1600 kilocalories per day. This meant that hunger was widespread (van der Eng, 2000).

\section{The "New Order" government of Suharto ${ }^{10}$}

In the early years of the Suharto government, pre-OPEC (1966-1973), there was a need to establish stability and consolidate political power. In this process, there was an important role for BULOG, the food logistics agency, in stabilizing rice prices, and donor assistance, especially the provision of food aid. Major investments were made to stimulate agriculture: irrigation rehabilitation, the introduction of high yielding varieties

\footnotetext{
${ }^{10}$ An excellent short summary of the Suharto years is in Bert Hofman's paper for the World Bank's conference in Shanghai in May, 2004. See Hoffman and Rodrick-Jones (2004). For greater detail, see Hill (1996) and the "Survey of Recent Developments" in each issue of the Bulletin of Indonesian Economic Studies. The brief "impressionistic" history provided here is based on these, and a wide variety of other, sources and personal recollections of working regularly in Indonesia through these times.
} 
(HYVs) of rice from IRRI, fertilizer imports and distribution, and the BIMAS program of extension and farm credits. Because median farm size was less than a hectare, rice intensification had widespread benefits, although larger farmers (with about one hectare of land) benefited the most in the early years.

Macro economic stability was achieved through a balanced budget and donor-provided foreign borrowing, with all proceeds to the Development Budget. Poverty fell rapidly as the economy stabilized and grew 5-6 percent per year in per capita terms, and as food production and overall food supplies rose sharply. Still, absolute poverty was thought to be about 60 percent in 1970. The first official poverty estimates, based on the 1976 SUSENAS, indicated a national poverty rate of about 40 percent.

Coping with high oil prices (1973-1983) is not the luxury it might seem for an oil exporter and member of OPEC. To be sure, there was rapid expansion of the economy as the role of the state expanded, but many were inefficient public-sector investments. Accompanying the real appreciation of the Rupiah was declining profitability of tradable goods production, especially in agriculture. During the mid-1970s there was a growing sense of income inequalities and severe poverty in rural areas, although the regional and commodity dimensions of the poverty masked its macro economic roots. The technocrats took a highly original strategic approach to what was then diagnosed as "Dutch Disease," with a surprise devaluation in November, 1978. After this, there was a rapid recovery of tradable goods production, especially in agriculture, with sharply falling poverty rates after 1978.

By the early 1980s the oil boom was over, and it became necessary to restructure the economy for a world of low commodity prices in world markets, the basic story from 1983 to 1993. Agriculture continued to grow, with stable prices for rice (that amounted to protection against the low prices in world markets), and aggressive exchange rate protection via devaluations in 1983 and 1986. Massive investments in rural infrastructure from earlier oil revenues begin to pay off in higher production and lower transactions costs for marketed goods (and improved labor mobility).

Industrial output surged in the latter part of the period, led by labor-intensive manufactured exports. Large scale and sustained economic deregulation lead to sharply better incentives for export, and these were matched by incentives for foreign direct investment (FDI). The fortuitous "push" in FDI from Japan as the yen appreciated rapidly, and the "pull" from the attractive climate in Indonesia allowed manufactured exports to play a significant role in employment generation by the end of the $1980 \mathrm{~s}$.

There was also a boom in the non-tradable economy. According to a model developed by John Mellor, production of non-tradable goods and services, especially in rural areas, provides the economic linkage between higher incomes from both agriculture and manufacturing wages, and pulling people out of underemployment in rural areas, and hence out of poverty (Mellor, 2000). The combined boom in agriculture, manufacturing, and non-tradables meant the period from the late 1970s to the mid-1990s is one of the most "pro-poor growth" episodes in modern economic history. This result is a surprise to 
many because the extensive economic restructuring that took place in the 1980s was thought to disadvantage labor.

Corruption and increasing distortions in resource allocation from 1993 to 1998 followed the interests of the Suharto family, especially the children (and grand children!). These interests distorted trade policy and public sector investments, with visible effects on competitiveness, which were partly masked by the inflow of FDI. As the economy boomed, deregulation lost steam, first in the BULOG commodities, then more broadly, with rapidly deteriorating performance (at least as measured by growth in total factor productivity). Poverty levels in 1996, the last SUSENAS report before the crisis, dropped to their lowest levels ever, with absolute poverty, measured in a comparable fashion to the poverty statistics reported first in 1976, falling below 12 percent. But the three decades of superb economic results were over. The Asian Financial Crisis hit in late 1997 and investors started to lose confidence in the ability of the Suharto government to cope, especially after the new cabinet was named in April, full of Suharto cronies and relatives. ${ }^{11}$ The crisis caused a massive depreciation of the Rupiah, which eventually led to chaos in the rice market. Spiraling rice prices late in 1998 led to huge increases in poverty, with estimates over 30 percent by the peak in late 1998 or early 1999.

\section{The "Democratic Era" (1999 - )}

Indonesia successfully elected a democratic legislature in 1999, which in turn selected a new president. With representative democracy came a new political economy of economic policy, especially from populist voices ostensibly speaking on behalf of the poor. An important test is underway to determine if Indonesia's pro-poor growth experience under a highly centralized and politically dominant regime has put down sustainable, even irreversible, roots, or whether the very foundations of the strategy will come undone under political challenge. Put bluntly, will what worked then work now?

Economic history has many examples of reversals of fortune, from the collapse of early civilizations to more modern experiences in Myanmar, Argentina and Zimbabwe. In the short run, politics is always the master of economics, but in the long run good economic governance is essential for growth. Indonesia has experienced its own reversals of fortune over the centuries, but the current challenge is unprecedented in the memories of most voters. It is already clear that the transition from the autocratic rule of Suharto, with economic policy designed and administered by an insulated group of skilled technocrats, to a politically responsive system with few public institutions in place to protect economic policy from polemicists, is going to be difficult for both economic growth and its connection to the poor. It is entirely possible that Indonesia will follow a path that looks more like Africa than East Asia ${ }^{12}$.

\footnotetext{
${ }^{11}$ A careful description of the unraveling of the Suharto regime from the perspective of an "insider" is in Stern (2003).

${ }^{12}$ See Artadi and Sala-i-Martin (2003) for an explanation of the economic policies that led to Africa's decline since 1960. Every variable in their list of contributing factors has direct parallels to issues now facing Indonesia.
} 
As is often the case, the evidence of deterioration is first seen in the market-sensitive agricultural and food sector. During the financial crisis, agricultural deregulation was forced on Indonesia by the IMF as a condition for assistance. The "Letter of Intent," signed by President Suharto in early 1998, established free trade in rice (and other BULOG commodities such as sugar, wheat and soybeans) for the first time since early Dutch days. After Suharto, the Indonesian government has responded to democratic pressures and organized interest groups by raising protection for sugar and rice production. Accompanying these actions has been a major political and economic debate over rice price policy and its impact on poverty. The stakes are high: the best estimate suggests that each 10 percentage points added on the rice tariff pushes an additional one million Indonesians below the poverty line, at least in the short run. Much controversy has been generated, in academic and political circles, over the dynamic and full general equilibrium effects of these pricing changes, and even the general media cover the issues (Warr, 2003; Fane and Warr, 2003).

Part of the donor effort to help Indonesia cope with corruption in the national government was to promote decentralization of political power. Domestic reform groups supported this agenda and responsibility for schools and most local services devolved to Kabupaten ("county") levels in 2002. However, not surprisingly, this transfer was made without adequate funding, policy guidelines, or training of local officials. Inevitably perhaps, corruption at the local level has become rampant, with evidence of local "trade" policies enforcing commodity taxes and trade barriers (especially for rice). Partly because of the resulting "compartmentalism" in the economy and the higher transactions costs for most economic activities caused by these activities, there is much donor interest and activity in improving local governance.

Indonesia has not recovered fully from the Asian Financial Crisis, at least in terms of average per capita incomes and health of the modern industrial and service economy. Recovery and restructuring are again the main items on the policy agenda. So far, growth has been led by domestic demand, as net foreign investment remains negative, leading to deep concerns about the "investment climate." On average, the rural economy has remained quite healthy after the significant depreciation of the Rupiah, but rural wages on Java apparently have not recovered to pre-crisis levels. There is a significant debate over this issue, however, because the rapid inflation during 1998 and 1999 has made it difficult to find appropriate deflators to calculate real wages. This debate has revealed a major paradox over poverty levels, as SUSENAS data show that poverty levels and the quality of dietary intake among the poor have returned to their pre-crisis lows, or better, whereas real wage data suggest that areas with major pockets of poverty have not recovered (Molyneaux, 2003). 


\section{A model of pro-poor growth}

There have been three major sources of economic growth since the mid-1960s: economic recovery and rehabilitation of the existing capital stock and infrastructure; rapid growth in agricultural productivity because of new technology and massive new investments in rural infrastructure; and eventually the emergence of a dominant manufacturing sector, stimulated by foreign direct investment and exports.

The resulting growth was strongly pro-poor in each episode because policy management emphasized maximizing productivity for the two scarcest factors of production-land and capital. High productivity for land meant yield-enhancing technologies that were labor intensive - the Green Revolution varieties of rice, for example, responded dramatically to greater fertilizer applications, good water control, and careful agronomic management.

Working capital in the trade and marketing sector was very expensive, and a small-scale, labor-intensive marketing structure dominated until the rapid emergence of supermarkets after 2001. And despite efforts by the government to build capital-intensive, state-owned industries when the budget was flush with oil revenues, private sector manufacturing was always highly labor intensive.

The secret to pro-poor growth, then, not surprisingly, has been rapid growth at the macro level that was simultaneously labor intensive at the micro level. The importance of agriculture and the rural economy in this process is obvious. Where land was the scarce resource relative to labor, as on Java, labor-intensive cropping patterns using high-yield technologies were poverty reducing. Where land was abundant relative to labor, as in many parts of the Outer Islands, plantation crops yielded good incomes both for laborers and smallholders. If labor-intensive manufacturing had not taken off rapidly in the mid1980s, agriculture on the Outer Islands would probably have contributed more to propoor growth by offering migration opportunities from Java. As history turned out, however, more opportunities beckoned on Java than off, and net migration to the "overcrowded" island remained positive from the 1970s onward.

Thus high labor intensity of output, on average and at the margin, characterized the most pro-poor episodes of Indonesia's growth. When labor intensity slipped, and the capitaloutput ratio rose, poverty reduction slowed dramatically, as in the mid-1970s during the oil boom. This record suggests a non-linear relationship between the rate and composition of economic growth and its impact on poverty, a relationship that might be conceptualized as an "acceleration model" of pro-poor growth.

This "acceleration model" attempts to show why real wages connect the poor to the growth process in a non-linear but symmetric fashion. Figure 3 shows the basic model as a stylized relationship between the rate of growth in the incomes of the poor (however defined) and the rate of growth in per capita incomes for the overall economy. Most empirical evidence suggests that the relationship is basically linear, with a slope of one. But at least in Asia, and especially in Indonesia, the relationship seems to be linear only within some "normal" range of economic growth. Outside that range, say from 0 percent 
to +5 percent per capita per year for the whole economy, the structure of the relationship seems to change, with impact on the poor accelerating at each end. The empirics to test this model are a major and separate undertaking, but the data in Figure 2 and 2 a show a hint of the relationship. For both China and Indonesia, the most "pro-poor" episodes were also the periods of fastest growth on average. From 1987 to 1990 in Indonesia, for example, average growth per capita was 5.7 percent per year at the same time that incomes of the bottom quintile grew by 10.8 percent per year. Recall that in China from 1980 to 1984 , average growth per capita was 8 percent per year while incomes of the bottom quintile grew a remarkable 14.6 percent.

The acceleration model is a variant of the Mellor model of growth in production of nontradables as the main mechanism pulling the rural underemployed out of poverty. In Mellor's interpretation, the non-tradables sector is demand constrained. Thus only rapid growth in incomes in households that purchase the goods and services produced by this sector can stimulate rapid poverty reduction. Historically, the sources of such growth have been rapid increases in the incomes of commercial agricultural households, and somewhat later, in the incomes from wage labor in the manufactured export sector. When both commercial agriculture and the manufactured export sector are booming, demand for non-tradable goods and services also booms, leading to the accelerated impact on poverty reduction.

\section{The components of the model}

Even a casual reading of the memoirs of the technocrats responsible for designing economic policy in the early years of the Suharto regime reveals their emphasis on the critical importance of economic growth as the only way to reduce poverty (Thee, 2003). As noted in the historical introduction, their assessment of the economic situation in late 1966 suggested that nearly the entire population was poor by absolute standards - half the per capita income of India at the same time, for example. In the short-term, there was simply no choice but to stress economic growth over poverty reduction - there was nothing to "redistribute."

In the longer-run, of course, strategic choices were available. With the disastrous experience of "politics in command" of the economy under Sukarno vividly in everyone's mind, the early strategy focused on stabilizing macro economic policy through a balanced budget and a realistic exchange rate, stabilizing the food economy by controlling rice prices (using market-compatible interventions), and rehabilitating infrastructure using the proceeds from foreign aid (and, later, oil revenues). Trade and investment policy was opened, with a dramatic liberalization of the capital account. The external environment was not particularly hospitable, as global inflation was very high and the United States was deeply engaged in Vietnam. But this permitted the Indonesian government to focus on developing its own strategy for economic growth. In particular, since neither Suharto nor the technocrats had any experience in policy making, the mechanisms of economic governance needed to be designed almost from scratch into a workable set of relationships and division of responsibilities. 


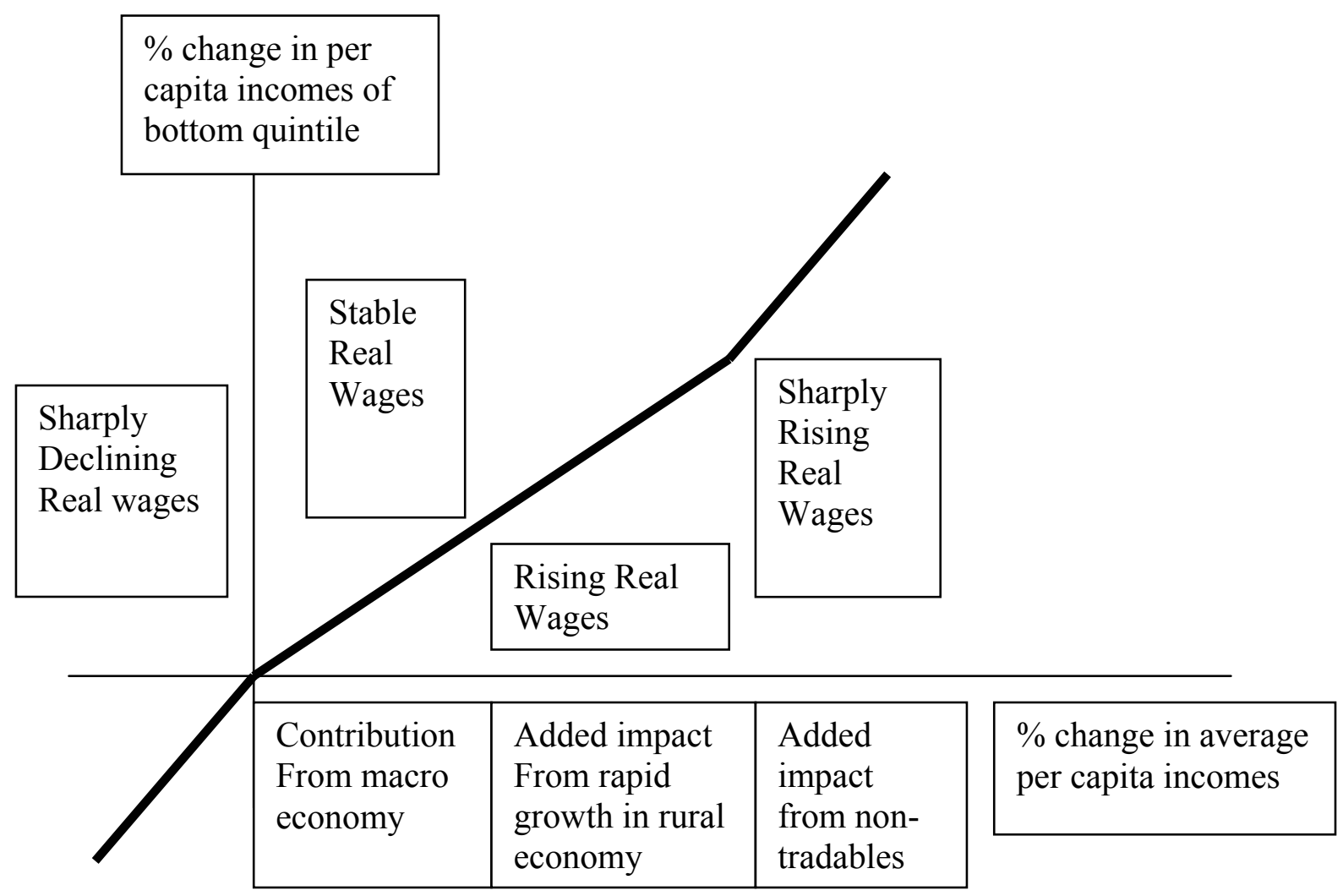

Figure 3. "Acceleration Model" of Pro-Poor Growth

Paradoxical as it seems now, it was Suharto himself who stressed to the technocrats the importance of connecting the poor to economic growth. Political scientists continue to debate why he was so concerned about this connection, but the reality is that much of the emphasis on improving the welfare of the rural population was initiated by the President (Rock, 2002, 2003: MacIntyre, 2001). He knew this was where most of the poor lived and that they could be helped through agricultural development, schools, clinics and family planning centers, and rural infrastructure investments. Out of this concern the technocrats evolved a development strategy that consciously tried to merge the ingredients of rapid economic growth with powerful connections to the livelihoods of the rural poor.

In retrospect, the pro-poor strategy encompassed three basic levels: improving the "capabilities" of the poor, lowering transactions costs in the economy, especially between rural and urban areas, and increasing demand for goods and services produced by the poor (or for their labor directly). These are illustrated in Figure 4. Macro economic policy was directly in the hands of the technocrats, and this was always managed to maximize the overall rate of economic growth, subject to controlling inflation through fiscal and monetary discipline. The exchange rate was an instrument of policy, not an objective except in the very short run, and it was managed to maintain profitability of 
producing tradable goods, especially in agriculture. Such a growth-oriented macro policy should call forth investments from the private sector that become the actual engine of economic growth, but the institutional foundations for rapid expansion of the private sector in Indonesia were not in place until the reforms of the 1980s, so a more active public role was necessary to stimulate appropriate investments. Apart from the mid1970s during the peak of the oil boom, the public role was not investments in state enterprises, but rather in the soft and hard supporting infrastructure for private sector enterprises.

These infrastructure investments lowered the costs of market connections that generated jobs and raised the productivity of the poor. Indeed, public sector investments and regulatory improvements to lower transactions costs as an approach to market development are arguably the crucial link between growth-oriented macro economic policy and widespread participation by poor households in the market economy. ${ }^{13}$ In Indonesia, these investments were in roads, communications networks, market infrastructure and ports, and irrigation and water systems. Many of them were built as labor-intensive public works, making millions of jobs available to unskilled labor willing to work at local market wages.

Lower transactions costs mean more market opportunities and faster economic growth, but they also mean easier access for the poor to markets and better connections to economic growth. For access to translate into participation, the capacity of poor households to enter the market economy needs to be enhanced. Thus, investments in human capital - education, public health clinics and family planning centers-improve the "capabilities" of the poor to connect to rapid economic growth. Of course, other barriers can also impede participation of rural households in market-led growth, hence the crucial importance of improved local governance to lower transactions costs with respect to property rights, market access, permits, education, etc.

The three-tiered strategy for pro-poor growth shown in Figure 4 links sound macro economic policy to market decisions that are facilitated by progressively lower transactions cost, which in turn are linked to household decisions about labor supply, agricultural production, and investment in the non-tradable economy. The rate of poverty reduction driven by this strategy depends on the array of assets controlled by the poortheir labor, human capital, social capital, and other forms of capital, including access to credit.

Modern finance theory provides the tools to measure the performance of this portfolio of assets. Factors influencing the "mean-variance" performance of an individual portfolio of assets held by the poor can be identified in both the short run and long run. Macro and trade policies affect asset prices, specific price policies affect the profitability of products produced and sold by the poor, factor market policies for land, labor and capital influence both the flexibility of response to these factor markets and their average returns.

\footnotetext{
${ }^{13}$ Sharp differences between transactions costs in Holland and colonial Netherlands East Indies (Indonesia) are offered as a major reason for their different development paths during the $18^{\text {th }}$ through the early $20^{\text {th }}$ centuries. See Zanden $(2003,2004)$.
} 
Figure 4. The Road to Pro-Poor Growth

Political Vision and Commitment

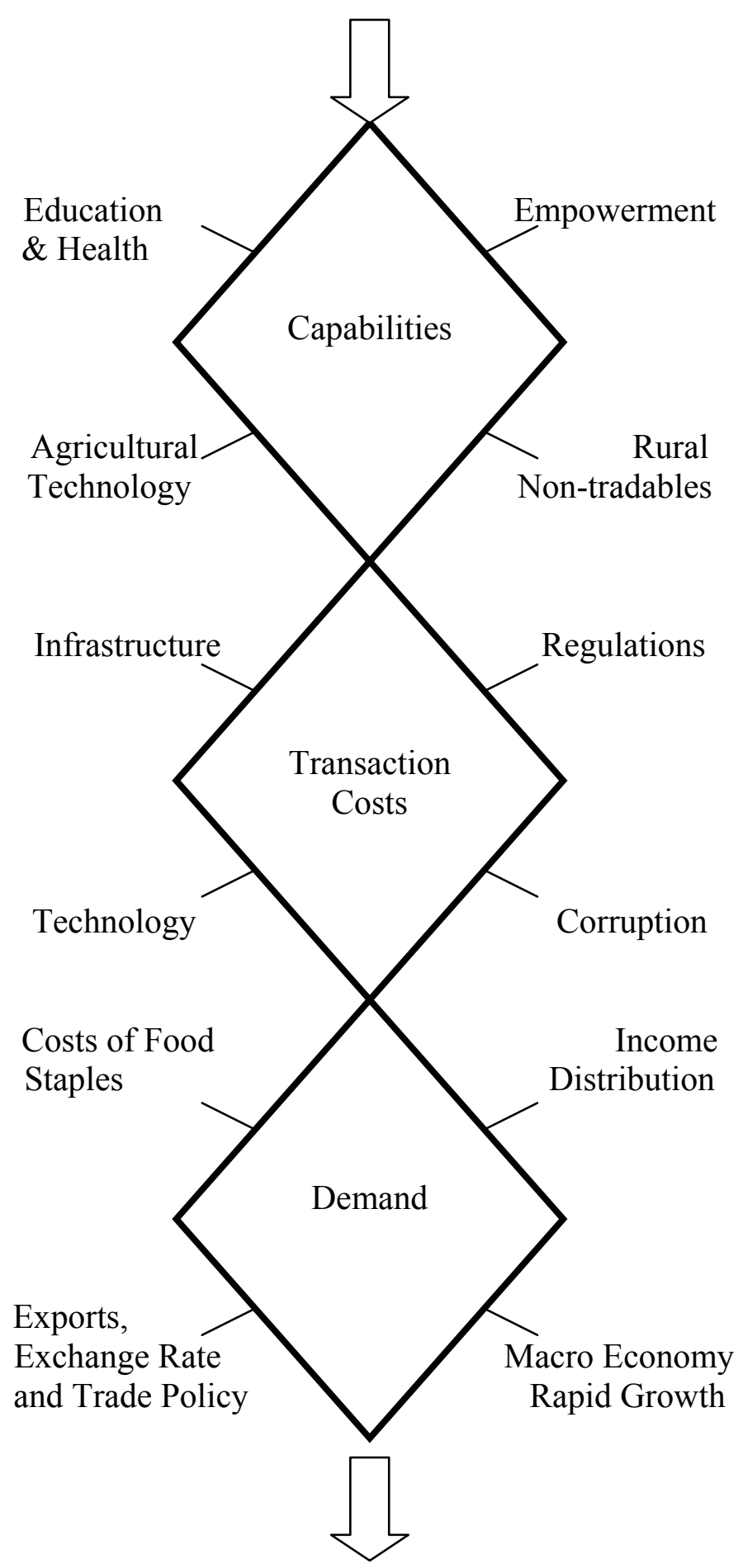

Rapid, Pro-poor Growth 
The most important way Indonesia attempted to influence returns to the portfolio of assets held by the poor was through human development expenditures, especially on education and public health. At least during the parts of the Suharto regime when the pro-poor strategy was most effectively implemented, there were few efforts to influence wage rates directly, and organized labor was actively suppressed. The technocrats closely monitored Indonesia's wages relative to competitors such as Malaysia and Thailand in the early years; China, Vietnam and India in the later years. The concern was always for job creation and the profitability of labor-intensive activities, especially for export.

An active price policy for rice also attempted to stabilize the returns to smallholders producing the commodity. At least until the mid-1990s, there was no long-run effort to raise these returns above trends in the world market, converted at the open-market exchange rate. The impact of this price stabilization policy on farm productivity, consumer welfare, and national food security was highly positive. According to finance theory, both farmers and consumers gain if the average prices they receive and pay are stabilized at their long-run mean. Reduced variance for the same mean improves the performance of a diversified asset portfolio, and reduced "noise" from price signals raises investment efficiency by improving signal extraction. Until the 1990s, the costs of this price policy, as implemented by the market-oriented operations of BULOG, were modest (Timmer, 1996).

How well does this strategy work? The answer depends on the efficiency of transmission mechanisms that connect the poor, through factor and product markets, to the overall growth process. The efficiency of these mechanisms depends on demand and supply pressures in the markets for unskilled labor and how well integrated these markets are across skill classes and regions. Initial conditions for income and asset inequalities seem to play an important role in the connection process, possibly because of failures in credit markets that make it hard for the poor to invest in their own human capital. Thus public investments in education and rural public health are likely to be necessary for the transmission mechanisms to work effectively for the poor (Gugerty and Timmer, 2000). Further, migration, job mobility, and flexibility in the face of shocks all help maintain upward mobility during the growth process, and cushion the irreversibility of suddenly falling into poverty seen in so many countries. Here a resilient rural economy has turned out to be crucial as a social safety net during the Crisis, as there was a sharp reversal of the structural transformation, and agriculture absorbed millions of displaced industrial and service workers (a process seen in Thailand as well during the Crisis).

The pro-poor growth strategy emphasized rapid increases in the demand for unskilled labor. A macro economic policy that stressed stability, to lower risks to investors, a competitive exchange rate, to keep tradable goods production profitable, and a monetary and fiscal policy that did not subsidize the use of capital, was the "umbrella" over the market economy. Markets were the arena for participation by the poor in economic activities that improved their productivity and household incomes. If the household economy is the "foundation" of the pro-poor strategy, with public investments used to improve their human capital and capabilities, the market economy is the bridge to the 
macro policy. This market economy is accessible to the poor only if the transactions costs of engagement are manageable and the risks are low.

Here too public investments are the key to making the process pro-poor. There are no doubt important trade-offs in how the public sector manages the array of investments needed, from human capital in rural areas to infrastructure that links rural households to market opportunities. Eventually all of these investments need to be made for pro-poor growth to succeed, and there is only limited evidence on sequencing when resources are critically short. Indonesia was able to make these investments faster because of large oil revenues in the 1970s, but most countries in similar circumstances squandered the largess. Why Indonesia carried out the pro-poor strategy as aggressively as it did remains a mystery of political economy.

\section{Facing the future: Policy trade-offs over pro-poor growth}

The connection between economic growth and poverty reduction was not severed in 1998. Although it seems likely that the poor were differentially impacted by the Financial Crisis during the months of rapid increases in real rice prices late in 1998, over the 3-year period from 1996 to 1999 for which detailed SUSENAS data are available, average per capita incomes fell 3.25 percent per year, whereas incomes in the bottom quintile fell "just" 1.15 percent per year. That is, there was a noticeable improvement in income distribution over the entire course of the crisis, despite the loss of real incomes for all classes. Active research efforts are underway in Indonesia to understand this puzzling result, but flexibility in the labor market and the massive depreciation of the rupiah (and thus increased profitability of producing tradable goods, especially in agriculture) are thought to be major factors. ${ }^{14}$

The issue is how to re-start rapid, pro-poor growth. The historical lessons argue that "growth at any cost" is not enough. What is needed is a growth strategy that is consciously designed to connect the poor. Of course, a return to rapid growth is essential to further reductions in poverty. But recognition of several important trade-offs along this path is also important.

\section{Trade-offs between sectoral policies with positive impact on the poor, and overall macro policies that speed economic growth in total}

There has been much nonsense in academic and policy circles in Indonesia with respect to targeting industrial policies on behalf of the poor. The arguments always involve industrial protection and inevitably raise the costs of inputs to labor-intensive industries. Agricultural protection (for sugar, especially) leads to high costs for food processors, and rice protection raises the cost of labor, inducing an anti-labor bias in the choice of rural technologies in small and medium enterprises. But, growth in agricultural productivity is clearly pro-poor, and such growth requires substantial public investments, and perhaps

\footnotetext{
${ }^{14}$ See Manning (2000) for a review of the arguments supporting flexible labor markets as a major factor, and Pearson, et al. (2003) for a discussion of the exchange rate effect on agriculture.
} 
even active price policy and support. There does seem to be a real trade-off between enhancing agricultural growth and keeping the economy fully open to trade, which stimulates faster overall economic growth. All the countries of Asia face this dilemma, especially in view of the distorted price incentives seen in world markets for most agricultural commodities. The distortions stem largely from protective agricultural policies in rich countries, but the poor countries themselves are not blameless either.

\section{Human capital investments versus investments in infrastructure that serves the poor}

There are very different time horizons for payoffs to human capital investments versus infrastructure investments: 15-20 years for education and child health, for example, and just 3-5 years for roads, ports, communications, market facilities, etc. What rate of time discount should be used for these decisions? What opportunity cost of capital? Does the government have to pay for all of these investments, or will partial subsidies and incentives work? The key trade-off is short-run versus long-run growth, and whether the poor can "wait" for payoff to their human capital. A "win-win" strategy might be for the poor to be actively engaged in building the infrastructure, thus earning income in the short run and being able to afford to keep their children in school, with its long-run payoff. Much more research needs to be done in this field and regional comparisons are likely to provide useful insights.

\section{Political economy trade-offs}

Are there general trade-offs between "payoffs" to ensure political stability (to individuals, industrial groups, students, military, labor unions, etc) and efficient resource allocation? Protection of farmers in East Asia during their rapid structural transformation is a case in point. The three fastest episodes of pro-poor growth historically have been Japan, Korea and Taiwan. These are also the three countries with the fastest growth in agricultural protection, and the highest levels at the end of the rapid growth period. Malaysia has experimented with similar protection for its rice farmers despite remaining an important exporter of other agricultural commodities. Indonesia is clearly on the verge of significant protection for rice farmers, despite its immediate impact on the poor.

More generally, political scientists speculate on the nature of the political coalition assembled by Suharto to maintain and strengthen his hold on power. This coalition was clearly held together by distribution of economic resources, often in the form of lucrative access to easily marketable commodities such as oil or timber. Import licenses for wheat, sugar and soybeans were also highly lucrative and were controlled closely by BULOG in the interests of the Suharto regime. Whether the pro-poor policies, and results, of the regime are tied to keeping these interest groups satisfied, even at the expense of faster economic growth in the short run, is the subject of active debate. 


\section{What now? The competing roles of politics and economics}

The Asian experience with pro-poor growth in general, and the Indonesian experience in particular, provide hope that desperately poor societies can escape from the worst manifestations of their poverty in a generation, provided appropriate policies are followed. This is an important message for the Indonesia of the future, unsure as it is over what path to follow during its democratic transition. The three-tiered strategy of growth-oriented macro economic policy, linked to product and factor markets through progressively lower transactions costs, which in turn are linked to poor households whose capabilities are being increased by public investments in human capital, is a general model accessible to all countries, including the future Indonesia. The pace of investments in infrastructure to lower transactions costs and in human capital to improve the capabilities of the poor will depend on each country's ability to generate public revenues. Finding pro-poor mechanisms of public finance will be crucial when foreign resources are not available, whether from donors or foreign oil consumers. These resources dictate the pace of growth as well as how pro-poor it is. With the right model in place, foreign assistance could have a very high payoff in both dimensions.

A number of other more specific insights emerge from the Indonesian story. The role of good economic governance and political commitment to poverty reduction is readily apparent, but the paradox is why the autocratic Suharto regime provided both ingredients for so long. Equally puzzling is why macro economic policy was left largely in the hands of very talented, but highly apolitical, technocrats. Persuasive arguments are made that they provided access to the donor community, which has been a strong, almost lavish, supporter of Indonesia since the late 1960s. On the other hand, trade policy protected special interests in the Suharto circle and even beyond, sometimes with no more apparent rationale than a nationalist interest to develop a modern industrial capacity. Similar patterns exist throughout Asia, so a basic mechanism in political economy would seem to be driving this pattern.

On a more technical level, managing "Dutch Disease" turned out to be difficult. The story of how the technocrats came to understand the issue, and how they mobilized Suharto's support for the surprise devaluation that emerged as the cure, shows the importance of good analysis and the depth of Suharto's commitment to reducing poverty in rural communities. In turn, this commitment also drove the sectoral priorities that led to massive investments in rural infrastructure, in rural human capital, and in the economic environment that made adoption of new agricultural technology highly profitable. There is speculation that part of this commitment came from the highly visible politics, and power, of food security. The drive for higher agricultural productivity was fueled at least in part by the desire for households, and the country, to have more reliable supplies of rice than what was available, at least historically, from world markets (Timmer, 2000). Here too the world has changed, and a drive for rice self-sufficiency that made economic sense in the early 1980 s would be folly today.

Perhaps the key lesson, then, is the need for flexibility in the actual components of the overall strategic vision. The three tiers seem to have general traction and applicability, 
but each country will have to figure out how to implement the vision within its own specific context and resources. For this, good analysis is essential. It needs political support to be effective, but politics alone cannot generate pro-poor growth.

\section{References}

Artadi, Elsa, and Xavier Sala-i-Martin. 2003. “The Economic Tragedy of the XXth Century: Growth in Africa. " NBER Working Paper No. 9865. Processed.

Booth, Anne. 2002. "Rethinking the Role of Agriculture in the 'East Asian' Model: Why is Southeast Asia Different from Northeast Asia?" ASEAN Economic Bulletin, Vol. 19, No. 1 (April), pp. 40-51.

Bulletin of Indonesian Economic Studies. "Survey of Recent Developments." Various issues.

Camerer, Colin, and Richard H. Thaler. 2003. "In Honor of Matthew Rabin: Winner of the John Bates Clark Medal.” Journal of Economic Perspectives. Vol. 17, No. 3 (Summer), pp 159-76.

Deininger, Klaus, and Lyn Squire. 1996 (with updates). "A New Data Set Measuring Income Inequality." The World Bank Economic Review. vol. 10, no. 3 (September), pp. 565-591. Data available at

http://www.worldbank.org/html/prdmg/grwthweb/growth_t.htm

Economist. 2004. "Special Supplement on 'Risk'." January 24-30, pp. S1-16.

Fane, George, and Peter Warr. 2003. "How Economic Growth Reduces Poverty: A General Equilibrium Analysis for Indonesia." In Ralph van der Hoeven and Anthony Shorrocks, eds., Perspectives on Growth and Poverty. WIDER: United Nations University Press. Pp. 217-234.

Galbraith, James K., and Hyunsub Kum (2003). "Estimating the Inequality of Household Incomes: Filling Gaps and Fixing Problems in Deininger \& Squire." UTIP Working Paper no. 22 (Revised), October 29. University of Texas, Austin: Processed.

Gugerty, Mary Kay, and C. Peter Timmer. 1999. "Growth, Inequality and Poverty Alleviation: Implications for Development Assistance.” Prepared for CAER II, USAID, Washington, DC. November.

Kraay, Aart. 2004. "When is Growth Pro-Poor? Cross-Country Evidence." World Bank Policy Research Working Paper 3225. March. Washington, DC: Processed.

Hill, Hal. 1996. The Indonesian Economy Since 1966. Cambridge University Press.

Hofman, Bert, and Ella Rodrick-Jones. 2004. "Indonesia: Rapid Growth; Weak Institutions." Paper prepared for the Shanghai Conference, May 28-29, 2004. Preliminary Draft (January). Jakarta: The World Bank, processed.

Islam, Iyanatul. 2002. "Poverty, Employment and Wages: An Indonesian Perspective." ILOJMHLW-Government of Indonesia Seminar on Strengthening Employment and Labour Market Policies for Poverty Alleviation and Economic Recovery in East and Southeast Asia. April 29May 1. Jakarta: ILO, processed. 
MacIntyre, Andrew. 2001. "The Politics of Agricultural Policy-making: the Importance of Institutions." In Ammar Siamwalla, ed., The Evolving Roles of State, Private, and Local Actors in Asian Rural Development. Oxford University Press, Hong Kong, pp. 243-70.

Manning, Chris. 2000. "Labour Market Adjustments to Indonesia's Economic Crisis: Context, Trends and Conclusions." Bulletin of Indonesian Economic Studies. Vol 36, No. 1 (April), pp. 105-36.

Mellor, John W. 2000. "Agricultural Growth, Rural Employment, and Poverty Reduction: NonTradables, Public Expenditure, and Balanced Growth.” Prepared for the World Bank Rural Week 2000, March.

Molyneaux, Jack. 2003. "Starchy Staple Consumption and Household Nutrition: A Fresh Look at Indonesian Welfare." Indonesian Food Policy Program (www.macrofoodpolicy.com), February, Jakarta: Processed.

Myrdal, Gunnar. 1968. Asian Drama: An Inquiry into the Poverty of Countries. Press?

Papanek, Gustav. 2004. “The Poor During Economic Decline, Rapid Growth and Crisis: The Case of Indonesia." Prepared for the USAID Project on Pro-Poor Growth conducted by DAI and BIDE, Bethesda, MD: processed.

Pearson, Scott, Sjaiful Bahri, and Carl Gotsch. 2003. "Is Rice Production in Indonesia Still Profitable?" Indonesian Food Policy Program (www.macrofoodpolicy.com), February, Jakarta: Processed.

Rock, Michael T., 2002. "Exploring the Impact of Selective Interventions in Agriculture on the Growth of Manufactures in Indonesia, Malaysia, and Thailand." Journal of International Development. Vol. 14, No. 4, pp. 485-510.

2003. "The Politics of Development Policy and Development Policy Reform in New Order Indonesia." William Davidson Institute Working Paper 632. (November), Processed. Pp. 1-56.

Sarris, Alexander H. 2001. "The Role of Agriculture in Economic Development and Poverty Reduction: An Empirical and Conceptual Foundation." Prepared for the Rural Development Department of the World Bank, Washington, DC. March.

Smith, Adam. 1776. An Inquiry into the Nature and Causes of the Wealth of Nations. See the edition of Smith's work based on Edwin Cannan's careful 1904 compilation (Methuen and Co., Ltd) of Smith's fifth edition of the book (1789).

Stern, Joseph J., 2003. "The Rise and Fall of the Indonesian Economy.” CID Working Paper, No. 100, Center for International Development, Harvard University, Cambridge, MA; Processed, pp. $1-42$.

Thee, Kian Wie (ed.), 2003. Recollections: The Indonesian Economy, 1950s-1990s. Singapore.

Timmer, Ashley. 1998. "Exit Options and Political Stability." Harvard University Department of Economics. Cambridge, MA: Processed.

Timmer, C. Peter. 1996. "Does BULOG Stabilise Rice Prices in Indonesia? Should it Try?" Bulletin of Indonesian Economic Studies. Vol 32, No. 2 (August), pp. 45-74. 
. 1997. "How Well do the Poor Connect to the Growth Process?" Harvard Institute for International Development, mimeo.

. 2000. "The Macro Dimensions of Food Security: Economic Growth, Equitable Distribution, and Food Price Stability." Food Policy. Vol 25, pp 283-295.

Timmer, C. P. 2002. "Agriculture and Economic Growth.” In Bruce Gardner and Gordon Rausser, eds., The Handbook of Agricultural Economics, Vol. II. Amsterdam: North-Holland. Pp. 1487-1546.

Timmer, C. Peter, Walter P. Falcon and Scott R. Pearson. 1983. Food Policy Analysis. Johns Hopkins University Press for the World Bank. Baltimore: Md.

Timmer, Ashley, and C. Peter Timmer. Forthcoming. "The Distributive Foundations of Economic Growth: An Essay on Behavioral Political Economy." Social Science Research Council and the Center for Global Development.

USAID. 2004. Pro-Poor Growth: A Guide to Policies and Programs. Prepared by DAI-BIDE for the USAID Office of Poverty Reduction. Washington, DC.

van der Eng, Pierre. 2000. "Food for Thought: Trends in Indonesia's Food Supply, 1880-1995." Journal of Interdisciplinary History. Vol. 30, No. 4, pp. 591-616.

. 2002. "Indonesia's Growth Performance in the Twentieth Century." In

Angus Maddison, D.S. Prasada Rao, and William F. Shepherd, eds. The Asian Economies in the Twentieth Century. Edward Elgar.

Warr, Peter. 2003. "Poverty and Food Policy in Indonesia." Working Paper, Australian National University. Processed.

World Bank. 1993. The East Asian Miracle: Economic Growth and Public Policy. Oxford University Press for the World Bank.

. 2004. "Operationalizing Pro-Poor Growth.” A Research Project Sponsored by AFD,

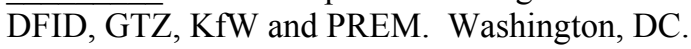

Zanden, Jan Luiten van. 2002. "On the Efficiency of Markets for Agricultural Products: Rice Prices and Capital Markets in $19^{\text {th }}$ Century Java." Paper for $62^{\text {nd }}$ annual meeting of the Economic History Association, October 11-13. St Louis, MO. International Institute for Social History, Processed.

. 2004. "On Global Economic History: A Personal View on an Agenda for Future Research.” Accessed at http://www.iisg.nl/staff/jvz.html 
Appendix 1: Variable List and Definitions

GDPGAP Average per-capita gross domestic product of the bottom income quintile subtracted from average per-capita GDP of the top income quintile. Calculated using Quintile income-share data from Emily Sinnott and Humberto Lopez, Pro-Poor Growth Database, World Bank 2003, and GDP data as defined below for GDPPC.

GDPGROW

Annual growth (percent) in per-capita GDP, calculated using GDP data as defined below, from the Summers-Heston Penn World Tables 6.1

GDPPC

Gross Domestic Product Per-Capita, in purchasing-power-parity adjusted US\$. From the Summers-Heston Penn World Tables 6.1

GDPSERV Percent of Gross Domestic Product Value Added from Services, from the World Bank, World Development Indicators Online, http://publications.worldbank.org/WDI/

GINI

Whole-Country Gini Index of Inequality, using the "high-quality" subset of data from Klaus Deininger and Lyn Squire, "Measuring Income Inequality: a New Database," http://www.worldbank.org/research/growth/dddeisqu.htm

GINISECT Computed Gini using only agricultural and non-agricultural shares of GDP and agricultural employment and non-agricultural employment shares. Data are from the World Bank, World Development Indicators Online, http://publications.worldbank.org/WDI/

KCALRESID Residuals from OLS regression: Caloric Intake $=\alpha+\beta^{*} \log ($ GDPPC). Average daily caloric intake data are from the Food and Agriculture Organization, FAOSTAT Agriculture Data, http://apps.fao.org/page/collections?subset=agriculture

RICEFTOB Ratio of annual average farm price of rice to world price, adjusted for milling using a 0.67 conversion factor. Price data from International Rice Research Institute, World Rice Statistics, Tables 18 and 24. http://www.irri.org/science/ricestat/index.asp

RICERTOF Ratio of annual average retail price of rice to farm price, adjusted for milling using a 0.67 conversion factor. Price data from International Rice Research Institute, World Rice Statistics, Tables 24 and 26. http://www.irri.org/science/ricestat/index.asp 
SAVING Gross Domestic Savings Rate, from the World Bank, World Development Indicators Online, http://publications.worldbank.org/WDI/

SSRRESID Residuals from OLS regression: Starchy-Staple Ratio $=\alpha+$ $\beta^{*} \log ($ GDPPC). The Starchy-Staple Ratio was computed using total average calorie intake and starchy-staple average caloric intake data from the Food and Agriculture Organization, FAOSTAT Agriculture Data, http://apps.fao.org/page/collections?subset=agriculture

THEIL

Theil Index of Manufacturing wage dispersion, from James Galbraith and Hyunsub Kum, "EHII: An Estimated Household Income Inequality Data Set for the Global Economy," http://utip.gov.utexas.edu/web/Data/EHIIUTIP22/introducingehii.htm

WAGEGAP Non-Agricultural Value Added per Worker divided by Agricultural Value Added Per Worker. Calculated using value-added data and employment shares from the World Bank, World Development Indicators Online, http://publications.worldbank.org/WDI/ 
Appendix Table 1: Variable Means, by country

\section{China Indonesia}

Gini Coefficient

Theil Index

Inter-sectoral Gini

Non-Agricultural/

Agricultural Wage Ratio

$\%$ of GDP from

$28.4 \%$

Services

$\%$ Growth in

per-capita income

Per-Capita Income (US\$PPP)

Gap between top and bottom quintile Income

$\%$ saving rate

$37.0 \%$

0.70

Ratio of retail

to farm rice prices

Starchy Staple Ratio

(residual from GDP regression)

Caloric Intake $-64.9$

(residual from GDP regression)

33.0

0.0826

64.5

3.0

$5.8 \%$

1904

707

794

$23.9 \%$

1.46

0.08

59.3
India

32.4

414

1935

2632

446

$18.5 \%$

$24.6 \%$

$32.2 \%$

$10.8 \%$

1.28

1.01

1.22

1.25

0.03

0.11

0.08

0.11

85.9

207.6

38.9

31.7

0.0460

66.3

3.0

$45.7 \%$

$2.9 \%$

1285

46

